University of Nebraska - Lincoln

DigitalCommons@University of Nebraska - Lincoln

Faculty Publications, Department of Psychology

Psychology, Department of

2010

\title{
Assessing School and Student Predictors of Weapons Reporting
}

Lindsey E. Wylie

University of Nebraska-Lincoln, slwylie@unomaha.edu

Chris L. Gibson

University of Florida, clgibson@ufl.edu

Eve M. Brank

University of Nebraska-Lincoln, ebrank2@unl.edu

Mark R. Fondacaro

City University of New York, mfondacaro@jjay.cuny.edu

Stephen W. Smith

University of Florida, swsmith@coe.ufl.edu

See next page for additional authors

Follow this and additional works at: https://digitalcommons.unl.edu/psychfacpub

Part of the Education Commons, and the Psychology Commons

Wylie, Lindsey E.; Gibson, Chris L.; Brank, Eve M.; Fondacaro, Mark R.; Smith, Stephen W.; Brown, Veda E.; and Miller, Scott A., "Assessing School and Student Predictors of Weapons Reporting" (2010). Faculty Publications, Department of Psychology. 978.

https://digitalcommons.unl.edu/psychfacpub/978

This Article is brought to you for free and open access by the Psychology, Department of at DigitalCommons@University of Nebraska - Lincoln. It has been accepted for inclusion in Faculty Publications, Department of Psychology by an authorized administrator of DigitalCommons@University of Nebraska - Lincoln. 


\section{Authors}

Lindsey E. Wylie, Chris L. Gibson, Eve M. Brank, Mark R. Fondacaro, Stephen W. Smith, Veda E. Brown, and Scott A. Miller 


\title{
Assessing School and Student Predictors of Weapons Reporting
}

\author{
Lindsey E. Wylie, ${ }^{1}$ Chris L. Gibson, ${ }^{2}$ Eve M. Brank, ${ }^{1}$ Mark R. Fondacaro, ${ }^{3}$ \\ Stephen W. Smith, ${ }^{2}$ Veda E. Brown, ${ }^{4}$ and Scott A. Miller ${ }^{2}$
}

1. University of Nebraska-Lincoln, Lincoln, Nebraska, USA

2. University of Florida, Gainesville, Florida, USA

3. City University of New York, New York City, New York, USA

4. Beaumont Independent School District, Beaumont, Texas, USA

Corresponding author - Eve M. Brank, University of Nebraska-Lincoln, P.O. Box 880308, Lincoln, NE 68588, USA, email ebrank2@unl.edu

\begin{abstract}
School violence and weapons at school are a major concern for community members, school administrators, and policy makers. This research examines both student-level and school-level variables that predict middle school students' willingness to report a weapon at school under several reporting conditions. Results substantiate previous analyses of these data that student-level variables explain students' willingness to report a weapon but extend these findings to include school climate variables that affect willingness to report (i.e., collective identity and conflict). School climate variables were also shown to influence reporting under conditions in which there would be consequences for the weapons-carrying student or for the reporting student; however, school climate was not found to influence anonymous reporting conditions. Although policies aimed at improving school climate may increase a student's willingness to report and are important in their own right, improving a school's climate may be a daunting task. This research, therefore, suggests that the most efficient way to encourage weapons reporting is to provide students with an anonymous way to report.
\end{abstract}

Keywords: weapons reporting, school climate, school violence 


\section{Introduction}

Although school-associated violent deaths account for less than $1 \%$ of homicides among school-age children (Anderson et al., 2001), there is widespread fear among parents and school officials that school shootings could take place in their community (Garcia, 2004; Sullivan, 2002). Moreover, students are also fearful of school violence and report that they are more afraid of being attacked in school than outside of school (Dinkes, Cataldi, \& LinKelly, 2007). With this emerging fear, and wave of media reports about school shootings, law enforcement and school officials are searching for solutions to reduce school violence generally and weapons-related violence more specifically.

Currently, several initiatives have emerged to target school violence. Most notable are zero tolerance policies that require a minimum 1-year suspension for weapons possession in school (Federal Gun-Free Schools Act, 1994). Schools have also implemented other preventative measures such as security cameras, the presence of law enforcement, random searches, locked entrances, duress alarms, and metal detectors to "beef up" security (Garcia, 2004; U.S. Department of Education, 2009). Most of these options, however, have generated some controversy. For example, random searches by school officials arguably violate students' rights (Beger, 2003) and are thought to be ineffective (Mawson, Lapsley, Hoffman, \& Guignard, 2002). Furthermore, metal detectors are very expensive, and their effectiveness is questionable (Garcia, 2004; Skiba et al., 2006; U.S. Department of Education, 2009).

Because these policies have not been met with much success, policy makers are exploring alternatives to these strict and punitive measures. In 2002, one such program was initiated by PAX (Real Solutions to Gun Violence), a nonprofit agency aimed at reducing gun violence toward children and families. The agency's "Speak Up" program is a national campaign that includes an anonymous hotline and public service announcements that encourage students to report other students who may be threatening violence or carrying a weapon to school (About Speak Up, 2006). In Tennessee, an effort called "Be Cool, Don't Let Guns Rule" is similarly encouraging students to report potential weapons at school and school events through an anonymous hotline as a joint effort between a local sheriff's office, Crime Stoppers, and the U.S. Department of Alcohol, Tobacco and Firearms (Koch, 2008). According to the Safe School Initiative, encouraging students to report a weapon is important because in approximately three-fourths of the recent school attacks, at least one person had information about the potential attack and in most cases this person was a peer, friend, school mate, or sibling (Vossekuil, Fein, Reddy, Borum, \& Modzeleski, 2002).

A recent study by Brank et al. (2007) explored student characteristics associated with willingness to report but did not examine school-level characteristics. Other research has indicated that accounting for school variables can further contribute to understanding predictive characteristics of student's behavior (e.g., Beaver, Wright, \& Maume, 2008; Bryk \& Raudenbush, 1992; Payne, 2008; Stewart, 2003; Wilcox \& Clayton, 2001) like weapons reporting. Therefore, the current research investigates how school characteristics may influence willingness to report weapon carrying, while extending the analyses from Brank et al. (2007), which accounted for student characteristics. Informed by research on school climate-school structural and social characteristics are examined to better understand how 
context might influence willingness to report and willingness to report under various situations. In other words, how are the correlates of weapons reporting different if reporting is anonymous, if there are known consequences for the person reporting, and if there are known consequences for the student carrying the weapon?

\section{Literature Review}

To date, research examining how school context influences adolescent behavior has largely focused on how school variables predict delinquency, violence, victimization, academic performance, and self-control (e.g., Anderson, 1982; Beaver et al., 2008; Burrow \& Apel, 2008; Brookmeyer, Fanti, \& Henrich, 2006; Payne, Gottfredson, \& Gottfredson, 2003; Plucker, 1998; Stewart, 2003; Turner, Piquero, \& Pratt, 2005; Welsch, Greene, \& Jenkins, 1999; Wilcox \& Clayton, 2001); however, how school contextual factors influence weapons reporting among students has received virtually no empirical attention. Furthermore, no research to date has examined both school climate factors that influence reporting and different circumstances in which students are willing to report other students carrying weapons.

Before describing the methods and data used for the current analysis, we discuss several key literatures on schools and weapons. First, we discuss the prevalence of weapons in schools and current policy initiatives surrounding school violence, weapons at schools, and aims at efforts to reduce school attacks. Then, we discuss the limited research that has assessed factors related to students reporting other students for carrying weapons at school. Finally, relying on research on school climate and community research, we discuss how schools that adolescents attend not only vary but how these contexts can influence reporting practices.

\section{Current Policies Addressing Weapons in School}

A national survey on school crime and safety found that approximately $6 \%$ of students reported carrying a weapon to school during the prior 30 days. Although from 1993 to 1999 the percentage of students carrying a weapon to school declined from $12 \%$ to $6 \%$, no measurable change has been observed from 1999 to 2007 (U.S. Department of Education, 2009). In a recent analysis of the 2001 School Crime Supplement of the National Crime Victimization Survey, consisting of a nationally representative sample of students, about $5 \%$ of students reported that they knew a peer had carried a weapon to school (Cao, Zhang, \& $\mathrm{He}$, 2008). Similarly, one in five students reported fear of being victimized with a weapon at school (Brown \& Benedict, 2004) and between $4 \%$ and $11 \%$ of students (varying across participating states) reported being injured or threatened with a weapon at school (U.S. Department of Education, 2009).

Endeavors for reducing weapons in school have focused on methods that reduce opportunities for weapons carrying by increasing associated risks and decreasing rewards (see Theory of Situational Crime Prevention [SCP] in Clarke, 1997). For example, school officials have increased security measures to now include security cameras, locker checks, metal detectors, the presence of security guards or police officers, increased adult supervision in hallways, and locked entrances (Garcia, 2004; Snell, Bailey, Carona, \& Mebane, 2002; U.S. Department of Education, 2009). With respect to metal detectors, a nationwide 
sample indicated that $10 \%$ of schools contained metal detectors in 2007 (U.S. Department of Education, 2009). Although metal detectors may reduce weapons in schools (Catalano, Loeber, \& McKinney, 1999), opponents argue that the advantages do not outweigh the disadvantages. School officials claim they are too expensive and are ineffective because monitoring students is difficult when the majority of students enter school just minutes before the bell (De Vise, 2008; Garcia, 2004). Furthermore, if a student is highly motivated to bring a weapon into school, the student could simply find an entrance that does not contain metal detectors because the expense for guarding all entrances would be prohibitive (Toby, 2002). In response to the high cost of metal detectors, some school districts purchase metal wands that security guards can use to randomly search students; however, occasionally searching students has not shown to be an effective method for preventing weapon carrying and use (Mawson et al., 2002).

The most ubiquitous policies have been punitive measures such as zero tolerance policies that require administrators to expel a student for 1 year if the student brings a gun on school property (Casella, 2003; Federal Gun Free Schools Act, 1994). Although these "tough on crime" policies are commonplace in most schools, some argue that zero tolerance policies are unsuccessful (Skiba et al., 2006). Proponents of such policies argue they have reduced weapons in schools; yet this reduction has not been empirically supported. Opponents of zero tolerance policies suggest that such intrusive security may actually cause more harm by interfering with the school's climate and educational environment (Beger, 2003; Skiba et al., 2006).

Because metal detectors are not an ideal solution and punitive "get tough" measures also may not be effective at reducing school violence, other types of programs to reduce weapons carrying in schools should be explored-especially programs to enhance communication among students (Brinkley \& Saarnio, 2006; Cao et al., 2008; Casella, 2003). Recently, programs have emerged, which attempt to increase communication within schools using anonymous tip lines, including "Be Cool, Don't Let Guns Rule" (Koch, 2008), and the PAX "Speak Up" (About Speak Up, 2006) initiatives. For the 2007-2008 academic year, the U.S. Department of Education (2009) reported that 31\% of schools had a structured anonymous threat-reporting system. In light of new programs such as these, some questions arise: How willing are students to report another student for carrying a weapon? What school-level factors may contribute to an increase in student weapon reporting? Moreover, under what circumstance or situation is a student most likely to report a weapon? And do those circumstances change based on the school climate?

\section{Students' Likelihood of Reporting}

Currently, limited research exists on students' willingness to report other students for bringing a weapon to school. Of the few studies that have examined weapons reporting, most have examined weapons reporting behavior at a single level of analysis (not accounting for the multilevel nature of student's behavior in schools). In these studies, weapons reporting has been attributed to student-related variables (Brank et al., 2007; Brinkley \& Saarnio, 2006; Friman et al., 2004; Newman, Murray, \& Lussier, 2001), parent-related variables (Brank et al., 2007), or school-related variables (Brinkley \& Saarnio, 2006). In addition, weapons reporting has been attributed to the conditions under which a student would 
report, such as anonymously (Brank et al., 2007) or when there are negative social consequences for reporting another student's delinquent behaviors (Friman et al., 2004; Schleidlinger, 2003).

Although not specifically explored in the student weapons reporting context, a theoretical explanation often explored in criminological offending and decision-making research concerns rational choice theories, which may explain students' willingness to report another student (often called "tattling"; e.g., Casella, 2003; Cornish \& Clarke, 1986; Klepper \& Nagin, 1989; Paternoster, 1989; Pratt, 2008). According to the theory, willingness to report another student's negative behaviors at school would be based on anticipated costs and benefits of reporting. For example, research has suggested that when students are asked to rate the likeability of their peers, they provide lower ratings of likeability to those they consider tattletales (Friman et al., 2004). Thus, students may view tattling on another student as contributing to negative social consequences that outweigh the benefits of reporting the student (Friman et al., 2004; Schleidlinger, 2003). Research on reporting and seeking help from school officials, however, assumes that middle school students perceive violence as negative and would therefore see the benefits of reporting it. However, a recent study found that the majority of students described past instances of violence at school as enjoyable (Kerbs \& Jolley, 2007), which may influence whether they would report the incident to a school official.

Another potential reason for a student's unwillingness to report weapons is a lack of attachment to conventional social ties. As explained by Wilcox Rountree (2000), students may carry weapons because they do not have strong ties or a strong stake in conforming to conventional institutional rules. Indeed, Wilcox Rountree cites that a number of studies have confirmed that a low social bond is positively related to weapon carrying. Similarly, students may be unwilling or simply unlikely to report because they lack the social bonds necessary to view weapons carrying as wrong.

Two studies to date have explored a student's willingness to report a potentially violent situation at school. The first is a descriptive study by Brinkley and Saarnio (2006) in which they surveyed students $(n=1,100)$ in four midsouthern schools about four issues: (a) knowledge of prior instances when another student has brought a weapon or threatened violence, (b) willingness to report a potentially violent incident, (c) their participation in a violent incident, and (d) their view of the school's climate. Results from this study suggest that younger female students were more likely to report a potentially violent situation. Furthermore, students who viewed the school unfavorably were less likely to report a potentially violent situation to an adult. Although the study of Brinkley and Saarnio (2006) is informative, its methods are mostly descriptive and thus unable to isolate the most important factors that influence willingness to report. Moreover, the data from this study include only four schools all located within the same geographic location.

Research by Brank et al. (2007) is the only known study that has used multivariate analyses to address students' willingness to report the presence of a weapon at school. This study explored factors such as connectedness with trusted adults, self-reported delinquency, and involvement with delinquent peers. The study aimed to identify the profile of a student most likely to report a weapon at school and the conditions under which a student is most likely to report. Findings suggested that students with more perceived adult 
or parent involvement are more likely to report a weapon and those who are delinquent and who associate with delinquent peers are less likely to report. In addition, the likelihood of reporting increased when the student could do so anonymously, if the weapon-carrying student was a friend.

\section{The Relationship between School Climate and Student Outcomes}

Several studies have linked student behaviors to the climate of the schools they attend. School climate and the effects on student behavior have their roots in the educational psychology literature (e.g., Anderson, 1982; Brookmeyer et al., 2006; Esposito, 1999; Loukas \& Murphy, 2007; Plucker, 1998; Reinke \& Herman, 2002; Ruus et al., 2007). However, research in criminology and delinquency has also recognized that a school's climate can greatly affect its students' behavior (e.g., Beaver et al., 2008; Payne et al., 2003; Stewart, 2003; Turner et al., 2005; Welsch et al., 1999; Wilcox \& Clayton, 2001) because schools are described as having a "personality" that can either inhibit or foster antisocial behavior (Anderson, 1982). School climate can be defined by several factors contributing to the overall environment of the school: ecological environment (size, building conditions), social milieu (race, gender, and socioeconomic status [SES]), organizational structure (curriculum and decision making), culture (peer and faculty norms; Anderson, 1982), and student connectedness (how connected a student feels to the school and other students; McNeely, Nonnemaker, \& Blum, 2002).

The most documented area of research on school climate has been the relationship of school climate with antisocial or delinquent behavior. In an analysis of 254 schools, Gottfredson, Gottfredson, Payne, and Gottfredson (2005) found that school climate variables explained more variance than community-based externally determined variables such as urbanicity, residential crowding, and poverty and disorganization. The results indicate that schools where students perceived the rules to be clear, fair, or enforced consistently had less delinquent behavior and less student victimization. A recent study examining middle school students' perceptions of school climate found that perceived student friction was significantly related to increased conduct problems (Loukas \& Murphy, 2007). Furthermore, in schools where students felt more connected, students had lower levels of misconduct (Payne, 2008; Payne et al., 2003; Stewart, 2003), were less likely to engage in violent behaviors at school (Murray \& Murray, 2004; Ochoa, Lopez, \& Elmer, 2007; Sprott, 2004), had lower levels of aggression (Reis, Trockel, \& Mulhall, 2007), were less likely to victimize other students (Burrow \& Apel, 2008), were less involved in crimes such as property offenses (Sprott, 2004), were less often exposed to weapons, and committed fewer weapons crimes (Brookmeyer et al., 2006). Studies have also suggested that school climate variables may be better at predicting less serious misbehavior, whereas individual-level factors may be more useful in explaining serious misbehavior (Welsh, 2001, 2003).

Although limited research has examined school climate and weapons reporting, Wilcox and Clayton (2001) used a multilevel model that assessed the effect of school-level and student-level variables on weapons carrying in school. Results revealed that the likelihood of carrying a weapon significantly varied across schools, even while controlling for studentlevel differences. School SES (as measured by the proportion of students on free school lunch) was a significant school-level predictor of weapons carrying; specifically, weapons 
carrying was more likely in schools having a higher proportion of students on free lunch. Interestingly, school SES was mediated by the school's "social capital," which is an indicator of established informal social controls and effective communication networks among students, parents, and administrators. According to the authors, a school climate that has greater "social capital" decreases the opportunity for delinquent behavior through informal social control, in contrast to a school climate with greater "schools deficit" (as indicated by difficulties in maintaining communication networks; Wilcox \& Clayton, 2001). Findings suggest that SES and a school's informal social control, as measured by school climate indicators, may help explain variations in students' behavior across schools and that school climate may be predictive of student's weapon-carrying behavior.

Although studies on school climate have largely centered on how school climate relates to antisocial behavior, research has also explored how school climate relates to prosocial behavior (Plucker, 1998; Reinke \& Herman, 2002; Ruus et al., 2007). Intervention research has shown that improving school climate may influence students' optimism, their psychological and physiological well-being, and academic success (Esposito, 1999; Ruus et al., 2007). School climate has also been associated with improved student social development (Esposito, 1999), an increase in future positive aspirations (Plucker, 1998), and a reduction in conduct problems for girls (Loukas \& Murphy, 2007).

\section{The Current Study}

In light of prior research acknowledging the importance of studying the effect of schoollevel variables on students' behavior, this study will advance prior research on weapons reporting to include analyses that examine the effects of both student variables and school climate variables on willingness to report a weapon. Moreover, the current research will also consider whether there are differences among students' likelihood of reporting under varying circumstances; such as when reporting is anonymous, when there may be consequences for the student with the weapon, and when there may be consequences for the student who reports.

It is hypothesized that individual-level student variables will still significantly contribute to whether a student would report another student with a weapon (Brank et al., 2007), but it is expected that school climate variables will also significantly contribute to whether a student would report a weapon. More specifically, schools that have a more positive school climate, independent of other school structural variables, will have students who are more likely to report a weapon. It is also hypothesized that school climate variables will differentially affect willingness to report under various reporting conditions. With respect to general willingness to report and willingness to report when consequences exist for either student, prior research suggests that a positive school climate would promote prosocial behavior such as reporting and decrease the occurrence of negative social consequences for reporting. However, it is hypothesized that school climate will not affect anonymous reporting. Specifically, Brank et al. (2007) found that anonymous reporting was an important variable for increasing a student's willingness to report; thus, anonymous conditions are most likely influenced by individual student characteristics and not influenced by external school climate factors. Results from this extension of the Brank et al. (2007) 
analysis will provide useful information for policy makers and school administrators to either amend or extend current policies. If our hypotheses are supported, then improving school climate may be more beneficial than policies implementing punishments as deterrents. Furthermore, in light of recent programs such as anonymous hotlines, understanding how school climate can affect students' weapons reporting under varying circumstances may provide insight to enhance the use of these anonymous reporting programs.

\section{Method}

\section{Data and Sampling}

As part of a larger project on middle school youth violence, 3,197 middle school students from 27 schools in five states (Florida, Texas, California, New Jersey, and Connecticut) participated in the current research (see Brank et al., 2007). The five states were chosen because they represented different geographic regions (e.g., Northeast, South, and West) and project members had prior contacts with schools in these states. Initial mail contacts with school district representatives were followed by e-mail and phone contact. From the 27 schools that agreed to participate, we selected a random subset of classes (excluding special education) to participate. Caretaker permission forms were sent home in the sampled classrooms and the schools were paid two dollars for each returned form, whether or not the student's caretaker granted permission for participation. For schools with a high proportion of Hispanic students, consent forms were also written in Spanish.

Data collection took place in the school auditorium, cafeteria, library, or classroom. The researchers read a script at the beginning of each session by which students were informed that the survey was anonymous, participation was voluntary, and they could skip any questions that made them feel uncomfortable or that they did not wish to answer. Students were given up to $50 \mathrm{~min}$ to complete the survey. Once students finished with the survey, they placed it directly in a box rather than returning it to the researcher to ensure anonymity. Students were not compensated for their participation.

Participants' ages ranged from 10 to $16(M=12.62, S D=.02)$, and of the students sampled, $60.3 \%$ were female and $39.7 \%$ were male (coded as male $=0$, female $=1)$. The racial and ethnic distribution of the sample was Hispanic (31.9\%), followed by White (31.36\%), Black (19.31\%), Multiracial or Other (10.92\%), Asian (3.59\%), and Native American (2.91\%; all dummy coded with White $=0)$. Students were evenly distributed across all three grades, with the majority of students in 6th grade (36.97\%), followed by 7 th grade $(33.63 \%)$, and then 8 th grade $(29.40 \%)$. Academic performance was measured by asking students what grades they received the previous school year. Students in the current sample reported above-average grades, with more than $50 \%$ of students reporting they had received either "mostly A's" or "mostly A's and B's," over 30\% of students reporting they had received either "mostly B's" or "mostly B's and C's," and the remainder receiving grades of either "mostly C's" and below.

In Brank et al. (2007), a small number of students $(n=36)$ were excluded because their ages were out of range for a middle school student (i.e., 10, 15, or 16 years old). This was done because the objective of Brank et al. was to explore the profile of a middle school student most likely to report a weapon; thus, student demographic outliers were important 
to identify and remove. The current analyses, however, did not exclude students based on demographic outliers because our current objective was to explore school context variables and including these students was important for aggregating school-level variables because schools usually have students outside the "normal" age range.

\section{Dependent Variables}

\section{Likelihood of weapons reporting}

Four questions were used to measure willingness to report under different circumstances. The four reporting circumstances include general willingness to report, report if respondent can remain anonymous, report if there are consequences for the one reporting, and report if there are consequences for the student carrying the weapon.

A single question was used to generally assess whether students would report another student who brought a knife, gun, or other weapon to school and was dichotomously coded as no (0) or yes (1). In the current sample, $69.5 \%$ of students said they would report a student for carrying a weapon in school. To measure willingness to report under anonymous circumstances, one question was used and asked whether students would report another student if they could do so without giving their name and was dichotomously coded as no (0) or yes (1). In the current sample, $81.9 \%$ said they would report a student carrying a weapon to school if they could do so anonymously.

Two additional scales were used to measure whether students would report another student who had a weapon if there were consequences for the student carrying the weapon and if there were consequences for themselves (the "tattler" or reporter). Item responses were on a 4-point Likert-type scale of definitely would not report (coded 1), probably would not report (coded 2), probably would report (coded 3), and definitely would report (coded 4). Higher scores on these measures indicated a higher likelihood of reporting another student. First, students' responses to the two questions were averaged to measure whether students would be willing to report even if there were consequences for the weaponscarrying student. One asked whether students would report if they thought the weapon carrier might get into trouble $(M=2.88, S D=1.03)$ and the other question asked whether they would report if the student carrying the weapon might get arrested $(M=2.82, S D=$ 1.08; Cronbach's $\alpha=.85)$. Second, students' responses to three questions were summed and averaged to measure the likelihood of reporting if negative consequences for the respondent could result. These included whether students would report if the weapons-carrying student might find out they told $(M=2.41, S D=1.05)$, if they thought the weapon carrier may hurt them $(M=2.70, S D=1.23)$, and if others might think of them as a snitch or tattletale $(M=2.51, S D=1.09$; Cronbach's $\alpha=.68)$.

\section{Individual Student-Level Variables}

\section{Demographics}

The demographics information assessed in this survey were age, gender, race/ethnicity, grade in school, and academic performance (described earlier). 


\section{Relationship with adults}

Using a modified Presence of Caring-Individual Protective Factor Index (Phillips \& Springer, 1992), a 12-item scale was created to measure relationship with adults (either parents or other adults). Examples of statements used in this scale are "There is a trustworthy adult I can turn to for advice," and "There are people I can depend on to help me if I really need it." The original questions had four answer choices including "YES!," "yes," "no," and "NO!" and were modified to Really true for me (coded 1), True for me (coded 2), Sort of true for me (coded 3), and Not true for me (coded 4). The remaining three questions were developed specifically for this study and asked about (a) the presence of an adult at school the student could trust, and how often the student talked with parents about, (b) how the student was doing at school, and (c) how things were going at school. The last two questions had answer choices from a 5-point Likert-type scale ranging from every day to never. Students' responses to all 12 items were summated to create a total measure of adult presence with higher scores representing students who have less adult presence $(M=29.27, S D=5.56$; Cronbach's $\alpha=.81$ ).

\section{Self-reported delinquency}

A reduced version of the Self-Reported Delinquency Scale (SRDS) was included to measure the respondent's own delinquency (Elliot, 1983). Thirty-four items were used, and response choices were on a 5-point Likert-type scale including never (coded 1), seldom (coded 2), sometimes (coded 3), fairly often (coded 4), and often (coded 5). For example, participants were asked to indicate how often in the last year they had "purposely damaged or destroyed property belonging to the school," "run away from home," "been drunk in public places," and "stolen (or tried to steal) a motor vehicle, such as a car or motorcycle." Higher scores on the SRDS indicate a student who has engaged in more delinquent behavior within the previous year $(M=1.52, S D=.70$; Cronbach's $\alpha=.97)$.

\section{Peer delinquency}

A reduced version of the Elliot Deviant Actions by Friends Scale (Peers) was included as a measure of delinquent peers (Elliot, 1983). Thirteen items were used and responses were on a 5-point Likert-type scale including none of them (coded 1), very few of them (coded 2), some of them (coded 3), most of them (coded 4), and all of them (coded 5). For example, the Peers measure asked students to indicate how often in the last year their close friends had "cheated on school tests," "stolen something worth more than $\$ 50$," and "sold hard drugs such as heroin, cocaine, and LSD." Higher scores indicate a student who has more peers who have engaged in delinquent acts within the previous year $(M=1.72, S D=.79$; Cronbach's $\alpha=.94)$.

\section{Aggregated School-Level Variables}

\section{Structural variables}

Two structural variables were included as school-level variables: school size measured by the total number of students in the school and school SES measured by the percentage of students on free or reduced school lunches. 


\section{School climate}

Student-perceived school climate was measured using the School Climate Survey (SCS) adapted from a middle school study on conflict resolution programs (see Smith, Daunic, Miller, \& Robinson, 2002), which contains 31 items with a 5-point Likert-type scale ranging from strongly disagree to strongly agree. Students' scores were aggregated to the school level. Mean values for each school were used as a measure for student-perceived school climate differences across schools. The SCS scale contains 5 subscales: collective identity (Cronbach's $\alpha=.84$ ), student cohesiveness (Cronbach's $\alpha=.66$ ), mutual respect (Cronbach's $\alpha=.78$ ), order and discipline (Cronbach's $\alpha=.67$ ), and school conflict (Cronbach's $\alpha=.71$ ). Collective identity includes 5 items such as "This is one of the best schools around" and "Teachers are proud to work here." Student cohesiveness includes 6 items such as "Students make new students feel welcome" and "Teachers and students have fun together." Mutual respect includes 7 items such as "Teachers treat students like they are responsible and trusted" and "Teachers understand problems and try to help." Order and discipline includes 6 items such as "The discipline code is administered unevenly, inconsistently, and unfairly" and "Misbehaving students are dealt with quickly" (reverse coded). Finally, school conflict includes 7 items such as "There are many disagreements among students in this school" and "Students express anger appropriately at this school" (reverse coded). Higher scores on the positive subscales of the SCS (i.e., collective identity, student cohesiveness, mutual respect, and order and discipline) reflect higher perceived occurrences of these constructs within the school; higher scores on school conflict reflect a school perceived as having lower occurrences of conflict.

\section{Analytic Strategy}

Students in the sample were nested within 27 schools and because of this clustering, students attending the same school may be more similar to one another than students attending different schools. This often results in a lack of independence in that the residuals for students in the same school will be correlated with one another. In this case, typical linear and logit regression estimates are inapt because standard errors become artificially deflated. To correct for this potential problem, we estimate our linear and logistics regression models using Huber-White corrections for standard errors. This corrective procedure takes into account that our data are clustered (i.e., students are within schools) by producing unbiased coefficients and standard errors. Several researchers have used this method when dealing with nested data and more specifically when estimating individual and structural influences on subjects (Bellair \& Roscignio, 2000; Stewart, Schreck, \& Simons, 2006).

Our analysis unfolds in a stepwise fashion using a series of linear and logistic regressions. Due to multicollinearity concerns, for each weapons reporting outcome, we estimate five regression models so that each includes one of the five school climate variables while simultaneously accounting for individual student demographic characteristics, delinquent peers, self-report delinquency, relationships with trusted adults, and structural aspects of schools (size and percentage on school lunch). For each analysis discussed below, students were removed using listwise deletion procedures. In other words, students who had missing data for any of the variables of interest for that regression were removed from that model. Therefore, because the four dependent measures were analyzed separately and 
missing values would vary across these four dependent measures, the number of participants in each regression analysis is different (see Tables 1-4 for sample sizes).

\section{Results}

\section{General Willingness to Report}

Table 1 shows a series of models predicting whether a student would be willing to report another student who carries a weapon to school. The five models show a general trend in that several student-level characteristics consistently predict willingness to report weapons carrying. Of the demographic characteristics, age and Hispanic status are significantly related to willingness to report. Younger students were more willing to report than older students. Hispanic students were less willing to report than White students. Accounting for school characteristics and upholding the findings from previous analysis of this data (Brank et al., 2007), delinquent peers and self-report delinquency had significant, negative effects on willingness to report. Students having fewer delinquent peers were more willing to report weapons carrying than those who had more delinquent peers, and students less involved in delinquency were more willing to report than those involved in more delinquency. Furthermore, having relationships with adults had a positive, statistically significant influence on willingness to report, indicating that students who were bonded with adults were more willing to report weapons carrying by other students than those who were not. The five models in Table 1 also reveal that after adjusting for individual-level factors, school characteristics are important predictors of willingness to report weapons carrying. Although structural characteristics of schools (i.e., school size and school SES) did not significantly influence willingness to report, school climate did matter. Both collective identity and school conflict have significant, positive influences on students' willingness to report. Students were significantly more willing to report weapons carrying in schools that had stronger collective identities and schools that had less conflict.

\section{Willingness to Report If Consequences for Student with Weapon}

Next, as shown in Table 2, we examined whether a student would report another student if the reporting student thought there would be consequences for the student with the weapon. A similar pattern of results emerges at the individual level for this outcome as has been shown for the prior willingness to report outcomes in Table 1. Consistently, students who are younger are significantly more willing to report weapon carrying when consequences for the weapon carrier are present. Hispanic students are less willing to report when there are consequences for the weapon carrier than White students, but this was not a consistent significant effect. Once again, delinquent peers, self-report delinquency, and relations with adults had significant influences on willingness to report when there were consequences for the weapon carrier. Those who had more delinquent peers were involved in more delinquency and had weakened relations with adults were less willing to report; those with less delinquent peers, less involved in delinquency, and stronger bonds to adults were more willing to report. Similar to the general willingness to report measure in Table 1, two school climate variables exhibited positive and significant influences on students' willingness to report when there are potential negative consequences for the 
weapon carrier. Students were more willing to report in schools that have stronger collective identities. Furthermore, students attending schools with less conflict were also more likely to report compared to students attending school with less conflict.

\begin{tabular}{|c|c|c|c|c|c|}
\hline Parameter & $\begin{array}{l}\text { Collective } \\
\text { Identity }\end{array}$ & $\begin{array}{c}\text { Student } \\
\text { Cohesiveness }\end{array}$ & $\begin{array}{l}\text { Mutual } \\
\text { Respect }\end{array}$ & $\begin{array}{l}\text { Order and } \\
\text { Discipline }\end{array}$ & Conflict \\
\hline \multicolumn{6}{|l|}{ Individual variables } \\
\hline Age & $-0.32^{* *}(0.07)$ & $-0.30^{* *}(0.07)$ & $-0.31^{* *}(0.07)$ & $-0.31^{* *}(0.07)$ & $-0.30^{* *}(0.07)$ \\
\hline Gender & $0.01(0.10)$ & $-0.01(0.10)$ & $-0.01(0.10)$ & $-0.01(0.10)$ & $0.01(0.10)$ \\
\hline \multicolumn{6}{|l|}{ Race } \\
\hline Black & $0.12(0.19)$ & $0.16(0.18)$ & $0.17(0.18)$ & $0.16(0.18)$ & $0.15(0.18)$ \\
\hline Hispanic & $-0.38^{+}(0.15)$ & $-0.31^{+}(0.15)$ & $-0.30(0.16)$ & $-0.30^{+}(0.15)$ & $-0.30^{+}(0.14)$ \\
\hline Native American & $0.36(0.24)$ & $0.33(0.25)$ & $0.33(0.25)$ & $0.33(0.25)$ & $0.36(0.24)$ \\
\hline Asian & $-0.66(0.29)$ & $-0.59(0.30)$ & $-0.59(0.30)$ & $-0.59(0.30)$ & $-0.60^{+}(0.30)$ \\
\hline Grades in school & $-0.04(0.03)$ & $-0.04(0.03)$ & $-0.04(0.03)$ & $-0.04(0.03)$ & $-0.01(0.03)$ \\
\hline Delinquent peers & $-0.40^{* *}(0.06)$ & $-0.40^{* *}(0.06)$ & $-0.41^{* *}(0.06)$ & $-0.40^{* *}(0.06)$ & $-0.40^{* *}(0.06)$ \\
\hline $\begin{array}{l}\text { Self-report } \\
\text { delinquency }\end{array}$ & $-0.57^{* *}(0.07)$ & $-0.57^{* *}(0.06)$ & $-0.57^{* *}(0.06)$ & $-0.57^{* *}(0.06)$ & $-0.60^{* *}(0.07)$ \\
\hline $\begin{array}{l}\text { Relationship } \\
\text { with adults }\end{array}$ & $0.03^{* *}(0.01)$ & $0.03^{* *}(0.01)$ & $0.03^{* *}(0.01)$ & $0.03^{* *}(0.01)$ & $0.03^{* *}(0.01)$ \\
\hline \multicolumn{6}{|l|}{ School variables } \\
\hline School size & $0.01(0.01)$ & $0.01(0.01)$ & $0.01(0.01)$ & $0.01(0.01)$ & $0.01(0.01)$ \\
\hline $\begin{array}{l}\text { Socioeconomic } \\
\text { status (SES; school } \\
\text { lunch) }\end{array}$ & $0.01(0.01)$ & $0.01(0.01)$ & $-0.01(0.01)$ & $0.01(0.01)$ & $0.01(0.01)$ \\
\hline \multicolumn{6}{|l|}{ School climate } \\
\hline Collective identity & $0.48^{*}(0.18)$ & & & & \\
\hline $\begin{array}{l}\text { Student } \\
\text { cohesiveness }\end{array}$ & & $-0.17(0.33)$ & & & \\
\hline Mutual respect & & & $-0.3(0.44)$ & & \\
\hline $\begin{array}{l}\text { Order and } \\
\text { discipline }\end{array}$ & & & & $0.22(0.44)$ & \\
\hline Conflict & & & & & $1.04(0.31)$ \\
\hline Constant & $4.02^{* *}(0.93)$ & $5.96^{* *}(1.40)$ & $6.36^{* *}(1.67)$ & $4.79 *(1.58)$ & $2.72^{*}(0.99)$ \\
\hline Log pseudolikelihood & $-1,188.27$ & $-1,191.02$ & $-1,191.76$ & $-1,191.99$ & $-1,186.77$ \\
\hline Chi-square & 279.95 & 407.69 & 454.23 & 423.81 & 412.27 \\
\hline Probability $>\chi^{2}$ & 0.001 & 0.001 & 0.001 & 0.001 & 0.001 \\
\hline Pseudo $R^{2}$ & 0.12 & 0.12 & 0.12 & 0.12 & 0.12 \\
\hline
\end{tabular}

Note: Standard errors are in parentheses.

$+p<.05$

${ }^{*} p<.01$

${ }^{* *} p<.001$ 
Wylie et Al., Youth Violence and JuVENile Justice 8 (2010)

Table 2. Logistic Regression Models for Predicting Willingness to Report If Consequences for Student with Weapon $(N=2,175)$

\begin{tabular}{|c|c|c|c|c|c|}
\hline Parameter & $\begin{array}{l}\text { Collective } \\
\text { Identity }\end{array}$ & $\begin{array}{c}\text { Student } \\
\text { Cohesiveness }\end{array}$ & $\begin{array}{l}\text { Mutual } \\
\text { Respect }\end{array}$ & $\begin{array}{l}\text { Order and } \\
\text { Discipline }\end{array}$ & Conflict \\
\hline \multicolumn{6}{|l|}{ Individual variables } \\
\hline Age & $-0.08^{* *}(0.02)$ & $-0.38^{* *}(0.02)$ & $-0.31^{* *}(0.07)$ & $-0.08^{* *}(0.02)$ & $-0.10^{* *}(0.02)$ \\
\hline Gender & $0.01(0.03)$ & $-0.01(0.03)$ & $-0.02(0.03)$ & $-0.01(0.03)$ & $0.01(0.03)$ \\
\hline \multicolumn{6}{|l|}{ Race } \\
\hline Black & $0.06(0.06)$ & $0.08(0.07)$ & $0.08(0.07)$ & $0.08(0.06)$ & $0.07(0.06)$ \\
\hline Hispanic & $-0.13^{*}(0.05)$ & $-0.10(0.05)$ & $-0.11(0.06)$ & $-0.10(0.05)$ & $-0.10^{*}(0.04)$ \\
\hline Native American & $0.01(0.13)$ & $-0.01(0.12)$ & $-0.01(0.12)$ & $-0.01(0.12)$ & $-0.01(0.13)$ \\
\hline Asian & $-0.01(0.10)$ & $0.02(0.10)$ & $0.02(0.10)$ & $0.02(0.10)$ & $-0.01(0.10)$ \\
\hline Grades in school & $-0.03(0.01)$ & $-0.03(0.01)$ & $-0.02(0.01)$ & $-0.03(0.01)$ & $-0.01(0.01)$ \\
\hline Delinquent peers & $-0.25^{* *}(0.03)$ & $-0.25^{* *}(0.03)$ & $-0.25^{* *}(0.03)$ & $-0.25^{* *}(0.03)$ & $-0.30^{* *}(0.03)$ \\
\hline $\begin{array}{l}\text { Self-report } \\
\text { delinquency }\end{array}$ & $-0.13^{+}(0.06)$ & $-0.12^{+}(0.05)$ & $-0.12^{+}(0.05)$ & $-0.12+(0.05)$ & $-0.10^{+}(0.06)$ \\
\hline $\begin{array}{l}\text { Relationship } \\
\text { with adults }\end{array}$ & $0.01^{* *}(0.01)$ & $0.02^{* *}(0.01)$ & $0.02^{* *}(0.01)$ & $0.02^{* *}(0.01)$ & $0.02^{* *}(0.01)$ \\
\hline \multicolumn{6}{|l|}{ School variables } \\
\hline School size & $0.01(0.01)$ & $-0.01(0.01)$ & $-0.01(0.01)$ & $-0.01(0.01)$ & $-0.01(0.01)$ \\
\hline $\begin{array}{l}\text { Socioeconomic } \\
\text { status (SES; school } \\
\text { lunch) }\end{array}$ & $0.01(0.01)$ & $0.01(0.01)$ & $0.01(0.01)$ & $0.01(0.01)$ & $0.01(0.01)$ \\
\hline \multicolumn{6}{|l|}{ School climate } \\
\hline Collective identity & $0.18^{+}(0.07)$ & & & & \\
\hline $\begin{array}{l}\text { Student } \\
\text { cohesiveness }\end{array}$ & & $-0.01(0.13)$ & & & \\
\hline Mutual respect & & & $-0.27(0.16)$ & & \\
\hline $\begin{array}{l}\text { Order and } \\
\text { discipline }\end{array}$ & & & & $-0.01(0.17)$ & \\
\hline Conflict & & & & & $0.32 *(0.12)$ \\
\hline Constant & $3.19^{* *}(0.32)$ & $3.74^{* *}(0.43)$ & $4.54^{* *}(0.53)$ & $3.73^{* *}(0.59)$ & $2.87^{*}(0.35)$ \\
\hline$F$ & 134.78 & 116.20 & 95.56 & 115.78 & 105.97 \\
\hline Probability $>F$ & 0.001 & 0.001 & 0.001 & 0.001 & 0.001 \\
\hline$R^{2}$ & 0.15 & 0.14 & 0.15 & 0.14 & 0.15 \\
\hline $\begin{array}{l}\text { Root mean square } \\
\text { error (RMSE) }\end{array}$ & .87 & .87 & .87 & .87 & .87 \\
\hline
\end{tabular}

Note: Standard errors are in parentheses.

$+p<.05$

${ }^{*} p<.01$

${ }^{* *} p<.001$ 
Wylie et al., Youth Violence and JuVenile Justice 8 (2010)

Table 3. Linear Regression Models for Predicting Willingness to Report If Consequences for Respondent $(N=2,158)$

\begin{tabular}{|c|c|c|c|c|c|}
\hline Parameter & $\begin{array}{l}\text { Collective } \\
\text { Identity }\end{array}$ & $\begin{array}{c}\text { Student } \\
\text { Cohesiveness }\end{array}$ & $\begin{array}{l}\text { Mutual } \\
\text { Respect }\end{array}$ & $\begin{array}{l}\text { Order and } \\
\text { Discipline }\end{array}$ & Conflict \\
\hline \multicolumn{6}{|l|}{ Individual variables } \\
\hline Age & $-0.07^{* *}(0.02)$ & $-0.07^{* *}(0.02)$ & $-0.07^{*}(0.02)$ & $-0.07^{*}(0.02)$ & $-0.10^{*}(0.02)$ \\
\hline Gender & $0.08^{+}(0.03)$ & $-0.09^{+}(0.03)$ & $-0.09 *(0.03)$ & $-0.09^{+}(0.03)$ & $-0.10^{+}(0.03)$ \\
\hline \multicolumn{6}{|l|}{ Race } \\
\hline Black & $0.18^{*}(0.05)$ & $0.20^{* *}(0.05)$ & $0.20^{* *}(0.06)$ & $0.20^{* *}(0.06)$ & $0.19^{* *}(0.05)$ \\
\hline Hispanic & $-0.11^{*}(0.04)$ & $-0.07(0.04)$ & $-0.07(0.04)$ & $-0.07(0.04)$ & $-0.10^{*}(0.03)$ \\
\hline Native American & $0.08(0.08)$ & $0.06(0.08)$ & $0.06(0.08)$ & $0.06(0.08)$ & $0.07(0.08)$ \\
\hline Asian & $-0.13^{+}(0.05)$ & $-0.10(0.06)$ & $-0.10(0.05)$ & $-0.10(0.06)$ & $-0.10(0.06)$ \\
\hline Grades in school & $0.01(0.01)$ & $0.01(0.01)$ & $0.01(0.01)$ & $0.01(0.01)$ & $0.01(0.01)$ \\
\hline Delinquent peers & $-0.25^{* *}(0.03)$ & $-0.25^{* *}(0.03)$ & $-0.25^{* *}(0.03)$ & $-0.25(0.03)$ & $-0.30^{* *}(0.03)$ \\
\hline $\begin{array}{l}\text { Self-report } \\
\text { delinquency }\end{array}$ & $-0.08(0.04)$ & $-0.07^{+}(0.04)$ & $-0.08(0.04)$ & $-0.08(0.04)$ & $-0.10(0.04)$ \\
\hline $\begin{array}{l}\text { Relationship } \\
\text { with adults }\end{array}$ & $0.01^{+}(0.01)$ & $0.01^{+}(0.01)$ & $0.01^{+}(0.01)$ & $0.01^{+}(0.01)$ & $0.01^{+}(0.01)$ \\
\hline \multicolumn{6}{|l|}{ School variables } \\
\hline School size & $0.01(0.01)$ & $-0.01(0.01)$ & $-0.01(0.01)$ & $-0.01(0.01)$ & $-0.01(0.01)$ \\
\hline $\begin{array}{l}\text { Socioeconomic } \\
\text { status (SES; school } \\
\text { lunch) }\end{array}$ & $0.01^{+}(0.01)$ & $0.01(0.01)$ & $0.02(0.01)$ & $0.01(0.01)$ & $0.01 *(0.01)$ \\
\hline \multicolumn{6}{|l|}{ School climate } \\
\hline Collective identity & $0.21^{* *}(0.05)$ & & & & \\
\hline $\begin{array}{l}\text { Student } \\
\text { cohesiveness }\end{array}$ & & $0.01(0.11)$ & & & \\
\hline Mutual respect & & & $-0.09(0.16)$ & & \\
\hline $\begin{array}{l}\text { Order and } \\
\text { discipline }\end{array}$ & & & & $0.01(0.14)$ & \\
\hline Conflict & & & & & $0.36^{*}(0.13)$ \\
\hline Constant & $2.88^{* *}(0.34)$ & $3.49^{* *}(0.36)$ & $3.77^{* *}(0.56)$ & $3.51^{* *}(0.55)$ & $2.56^{*}(0.43)$ \\
\hline$F$ & 46.70 & 92.62 & 53.06 & 56.82 & 51.92 \\
\hline Probability $>F$ & 0.001 & 0.001 & 0.001 & 0.001 & 0.001 \\
\hline$R^{2}$ & 0.12 & 0.12 & 0.12 & 0.12 & 0.12 \\
\hline $\begin{array}{l}\text { Root mean square } \\
\text { error (RMSE) }\end{array}$ & .82 & .82 & .82 & .82 & .82 \\
\hline
\end{tabular}

Note: Standard errors are in parentheses.

$+p<.05$

$* p<.01$

${ }^{* *} p<.001$ 
Wylie et al., Youth Violence and JuVenile Justice 8 (2010)

\begin{tabular}{|c|c|c|c|c|c|}
\hline Parameter & $\begin{array}{l}\text { Collective } \\
\text { Identity }\end{array}$ & $\begin{array}{c}\text { Student } \\
\text { Cohesiveness }\end{array}$ & $\begin{array}{l}\text { Mutual } \\
\text { Respect }\end{array}$ & $\begin{array}{l}\text { Order and } \\
\text { Discipline }\end{array}$ & Conflict \\
\hline \multicolumn{6}{|l|}{ Individual variables } \\
\hline Age & $-0.19^{+}(0.08)$ & $-0.18^{+}(0.07)$ & $-0.17^{+}(0.07)$ & $-0.18^{+}(0.08)$ & $-0.20^{+}(0.08)$ \\
\hline Gender & $0.11(0.09)$ & $0.11(0.09)$ & $0.09(0.09)$ & $0.10(0.09)$ & $0.10(0.09)$ \\
\hline \multicolumn{6}{|l|}{ Race } \\
\hline Black & $0.01(0.20)$ & $-0.01(0.20)$ & $0.03(0.20)$ & $0.04(0.20)$ & $0.04(0.20)$ \\
\hline Hispanic & $-0.09(0.18)$ & $-0.08(0.18)$ & $-0.06(0.18)$ & $-0.05(0.17)$ & $-0.01(0.17)$ \\
\hline Native American & $0.15(0.28)$ & $0.13(0.28)$ & $0.11(0.28)$ & $0.13(0.28)$ & $0.12(0.28)$ \\
\hline Asian & $0.02(0.42)$ & $0.02(0.42)$ & $0.04(0.42)$ & $0.05(0.42)$ & $0.06(0.42)$ \\
\hline Grades in school & $-0.04(0.04)$ & $-0.03(0.04)$ & $-0.03(0.04)$ & $-0.04(0.04)$ & $-0.01(0.04)$ \\
\hline Delinquent peers & $-0.55^{* *}(0.09)$ & $-0.55^{* *}(0.09)$ & $-0.56^{* *}(0.09)$ & $-0.55^{* *}(0.09)$ & $-0.60^{* *}(0.89)$ \\
\hline $\begin{array}{l}\text { Self-report } \\
\text { delinquency }\end{array}$ & $-0.56^{* *}(0.07)$ & $-0.56^{* *}(0.07)$ & $-0.56^{* *}(0.07)$ & $-0.56^{* *}(0.07)$ & $-0.60^{* *}(0.07)$ \\
\hline $\begin{array}{l}\text { Relationship } \\
\text { with adults }\end{array}$ & $0.04^{* *}(0.01)$ & $0.04^{* *}(0.01)$ & $0.04^{* *}(0.01)$ & $0.04^{* *}(0.01)$ & $0.04^{* *}(0.01)$ \\
\hline \multicolumn{6}{|l|}{ School variables } \\
\hline School size & $0.01(0.01)$ & $0.01(0.01)$ & $0.01(0.01)$ & $0.01(0.01)$ & $0.01(0.01)$ \\
\hline $\begin{array}{l}\text { Socioeconomic } \\
\text { status (SES; school } \\
\text { lunch) }\end{array}$ & $-0.01(0.01)$ & $-0.01(0.01)$ & $-0.01(0.01)$ & $-0.01(0.01)$ & $-0.01(0.01)$ \\
\hline \multicolumn{6}{|l|}{ School climate } \\
\hline Collective identity & $0.26(0.24)$ & & & & \\
\hline $\begin{array}{l}\text { Student } \\
\text { cohesiveness }\end{array}$ & & $-0.50(0.26)$ & & & \\
\hline Mutual respect & & & $-0.58(0.39)$ & & \\
\hline $\begin{array}{l}\text { Order and } \\
\text { discipline }\end{array}$ & & & & $0.08(0.42)$ & \\
\hline Conflict & & & & & $-0.3(0.39)$ \\
\hline Constant & $4.34^{* *}(1.32)$ & $6.56^{* *}(1.34)$ & $6.82^{* *}(1.48)$ & $4.86^{*}(1.72)$ & $5.97^{* *}(1.37)$ \\
\hline Log pseudolikelihood & -750.16 & -749.90 & -749.79 & -750.60 & -750.36 \\
\hline$\chi^{2}$ & 691.30 & 583.96 & 547.31 & 564.02 & 605.29 \\
\hline Probability $>\chi^{2}$ & 0.001 & 0.001 & 0.001 & 0.001 & 0.001 \\
\hline Pseudo $R^{2}$ & 0.16 & 0.16 & 0.16 & 0.16 & 0.16 \\
\hline
\end{tabular}

Note: Standard errors are in parentheses.

$+p<.05$

${ }^{*} p<.01$

** $p<.001$ 


\section{Willingness to Report If Consequences for the Student Reporting}

The findings predicting willingness to report a student for carrying a weapon to school when negative consequences may exist for the respondent (i.e., the student reporting or "tattling") are shown in Table 3. Although similarities are present, for this particular condition, the pattern of findings changes somewhat. Although age, delinquent peers, and relationships with adults retain their significant influences on willingness to report, several new findings emerge when there are potential negative consequences for the person who is reporting (e.g., the weapon carrier might hurt them or they might be thought of as a "snitch"). For instance, gender has a significant, negative influence on reporting, indicating that males are more likely to report than females. White students are now less likely to report than Black students when personal negative consequences may result. Although not a consistent finding across models, the collective identity model in Table 3 shows that Whites are more likely to report under these conditions than Hispanics and Asians. Until now self-reported delinquency has had a significant negative influence on reporting; however, under conditions where negative consequences could result for the one telling, those who are less involved in delinquency are no longer significantly more willing to report than those who are increasingly more delinquent. Finally, several school characteristics significantly influence the willingness to report under conditions where there could be negative consequences for the one reporting. Students who attend schools with lower SES are less willing to report under these circumstances, although this finding does not seem to be consistent across models. However, collective identity and school conflict both have positive and significant influences on willingness to report weapons carrying at school. Students who attend schools with stronger collective identities are more willing to report a student carrying a weapon at school even when there are potentially damaging or even dangerous consequences. In addition, students who attend schools that have less conflict are more willing to report a student carrying a weapon at school even when they face negative consequences for telling.

\section{Willingness to Report If Anonymous}

Finally, Table 4 shows results that predict whether students would be willing to report another student carrying a weapon if the respondent (the reporter or "tattler") remained anonymous. Of the demographic characteristics, age had a significant negative influence on willingness to report under anonymous conditions across the five models, indicating that younger students were more likely to report if they could remain anonymous compared to older students. Again, consistent with prior research and findings from Tables 1-3, delinquent peers, self-report delinquency, and relationships with adults, each significantly influenced willingness to report under anonymous conditions consistently across each of the five models in Table 4. Students having fewer delinquent peers were more likely to report than those having more delinquent peers, and students involved in less delinquency were more willing to report than those more involved. Even when no one would find out, the more delinquent students and those that hung out with delinquent peers still were less willing to report. Also consistent with earlier results, having stronger relationships with adults increased the willingness to report under anonymous conditions. As for school 
characteristics, none of the structural or school climate variables significantly influenced willingness to report weapons carrying under anonymous conditions.

\section{Discussion}

The purpose of the current research was to examine how school-level variables influence students' willingness to report the presence of weapons at school and to use the findings to make suggestions about possible school policies concerning weapons. As expected, school climate variables were generally important factors in determining when students would be willing to report weapons. This was not true when students were asked about reporting anonymously. In other words, students' willingness to report was not influenced by the school climate, if there was an anonymous way for the students to report. School structural variables (i.e., free and reduced lunch ratios and school size) were not important factors in determining when students would report. Because we are extending the analyses from Brank et al. (2007) to now account for school-level variables, it is important to note that the individual-level variables Brank and her colleagues examined such as own delinquency, peer delinquency, and adult attachments still consistently influenced students' willingness to report weapons.

The findings from the current analysis suggest two directions for policy makers interested in increasing students' willingness to report another student carrying a weapon to school. The first is to improve perceived school climate. A school's climate, specifically its level of collective identity and level of conflict, are important factors for middle school students in their beliefs about whether they would report weapons at their school. Thus, schools with a positive learning environment encourage students to report weapons even when there might be repercussions for the reporter or the weapon carrier. However, the structural variables of the school-school size and percentage of students receiving free or reduced lunch - were not important in predicting which students said they would report weapons. Obviously, these factors are important in predicting other outcomes such as weapons carrying, academic achievement, perceived safety for students, student victimization, and school crime (Burrow \& Apel, 2008; Chen, 2008; Chen \& Weikart, 2008; Lleras, 2008; Wilcox \& Clayton, 2001); but in the current analysis, school structural variables are not as relevant to weapons reporting.

Another direction for policy makers suggested by the current data is to implement an anonymous way for students to report weapons. Most notably from the current analysis, when students were asked about anonymous weapons reporting, the school climate factors were not important. It may be possible that if a school can implement an anonymous way to report weapons, similar to current systems like PAX's Speak Up that provide anonymous hotlines (About Speak Up, 2006), the students anticipate that they would be more likely to report, regardless of school climate. Although school officials should certainly strive to have a more positive school atmosphere, making such a change is probably easier said than done. Changing a school climate is not an easy task because school climate is a multidimensional construct (Koth, Bradshaw, \& Leaf, 2008) that would require several dimensions of improvement such as parent and community involvement, character education, violence prevention and conflict resolution, peer mediation, and bullying prevention 
(Peterson \& Skiba, 2001). In contrast, providing an anonymous way for students to report weapons is likely to be much easier.

Similar to the results from the research by Brinkley and Saarnio (2006), school climate seems to matter for students' general willingness to report weapons. The current research complements and extends the findings of Brinkley and Saarnio because their study took place in only one geographic location and used mostly descriptive analytic techniques. For the Brinkley and Saarnio study, the student-teacher relationship was the most important school climate variable in discriminating between students who would and those who would not report weapons at school. Brinkley and Saarnio did not ask about anonymous reporting but based on the current findings, we believe that the student-teacher relationship would not have been important if the students were asked about anonymous reporting because the current results suggest that school-level factors are not important when anonymous reporting is available.

In addition to school-level factors, the analysis accounted for student-level factors. The influence of individual-level factors was virtually unaffected by the different weapons reporting situations (i.e., potential consequences or anonymous). Although this may not inform school policies as much as the suggestions described above, it is important to note how students' characteristics may influence reporting while controlling for school influences. First, age was consistently a predictive factor in willingness to report weapons. As in the initial analyses by Brank et al. (2007), younger students were significantly more willing to report weapons. Our data are only cross-sectional, and although there could have been time-period differences between those students who were younger from those who were older, it is unlikely given the narrow range of ages (from ages 10 to 16). Rather, it is more likely that this effect results from the students' maturation. It may be that students who are older assume that they can handle the situation without informing a teacher. However, it could be that as students age, they become apathetic because they are accustomed to peers making empty threats. Unfortunately, the current project does not answer why age influences students' willingness to report, but we do know that policies concerning weapons reporting need to consider this age effect.

As expected, higher self-reported delinquency and higher peer delinquency were consistently predictive of a lower willingness to report, and better adult relationships were predictive of more willingness to report. As noted by Brank et al. (2007), those students who are unlikely to report the presence of a weapon in their school are, unfortunately, quite similar to the students who carry weapons to school. Previous research has demonstrated that those who are delinquent (Brown, 2004), those who have delinquent peers (Wilcox Rountree, 2000), and those with poor parent/adult relationships (Bailey, Flewelling, \& Rosenbaum,1997; Orpinas, Murray, \& Kelder, 1999) will be more likely to carry a weapon to school. This creates an unfortunate cycle. We know that carrying a weapon is related to other delinquent activities (Bailey et al., 1997; Estell, Farmer, Cairns, \& Clemmer, 2003; Malek, Chang, \& Davis, 1998); therefore, a student who is most likely to carry a weapon to school is also a student who has friends who are the least likely to report the weapon carrier.

Race and gender of the student respondents were either inconsistent or not useful in predicting willingness to report. Based on recent bullying research, the race effect may be influenced by not only the respondent's race but also their race in relation to the school's 
racial composition (Bellmore, Witkow, Graham, \& Juvonen, 2004). Boys and girls may not be different on willingness to report. It is also possible that self-perceived popularity may have suppressed any potential gender effects. Newman et al. (2001) examined whether students would seek teacher help in a hypothetical peer conflict situation. Boys in their sample who considered themselves popular were more likely to seek help from a teacher; yet girls who considered themselves unpopular were more likely to seek help from a teacher. The authors attribute these differences to the desire to be liked by peers and how this may be different for boys and girls.

In the current study, Hispanic students were less willing to report weapon carrying than White students. This finding should be further explored in future research to determine the reasons for this racial difference. Pershing (2003) provides one potential explanation in her study of occupational misconduct and snitching within the U.S. Naval Academy. Hispanic students may be experiencing a different kind of self-regulation and elevating peer loyalty above those students from other racial groups. In contrast, Harcourt (2000) suggests that such a finding might be because there are different social norms in effect. For example, snitching may work to alter the normal power incentives of gun carrying, but snitching could also lead to snitches being ostracized, devalued, or harmed. These potential explanations in the current sample were not explored but could be incorporated easily in future studies to determine how the social norms can and should be altered to encourage reporting. Another important future focus should be on the students' perceptions of the presence of weapons in their schools. For the current study, we did not ask students about their perception of the prevalence of weapons in their schools, but such an examination may be useful because perceptions of problems could change a student's response about their own level of fear and their willingness to report (See Astor, Benbenishty, Zeira, \& Vinokur, 2002).

We know that in a vast majority of school shooting incidents, the shooters told at least one other student about their shooting plans. This means that most of those incidents may have been preventable. The current research suggests that students believe they will be most likely to report weapons if there is an anonymous way to do so. Other factors certainly do contribute to a student's willingness to report, but from a policy perspective, it seems to make the most sense to simply provide students with the ability to anonymously report. Implementing and protecting anonymity should be a priority for schools that want to encourage students to report the presence of weapons. Although the effectiveness of anonymous hotlines was beyond the scope of the current research, the findings from this study suggest that future policy analysts may want to focus their attention on evaluating their effectiveness.

The use of nonprobability sampling techniques does limit the current research. Our sample is clearly not representative of the entire middle school student population; however, we did collect a racially and geographically diverse sample. In addition, our focus on a student's stated willingness to report weapons may not perfectly correlate with the student's actual willingness, but we believe that the confidentiality of the students' responses should increase the validity of their answers.

Past research has examined the individual factors that contribute to willingness to report weapons (Brank et al., 2007). The current project extended those results to school-level factors. Schools are known to have different climates and, as we found, a school's climate 
can influence a student's willingness to report weapons. The school's climate was influential but not when students could report anonymously. This suggests that future research should focus more closely on anonymous weapons reporting programs, in addition to understanding characteristics of students and schools that will increase anonymous reporting. If anonymity is that important for students, then it will be important to understand the situations that threaten to violate that anonymity. Similarly, it will be equally as important to understand how the students understand anonymity and what situations they deem to have appropriate levels of anonymity.

Acknowledgments - The authors would like to acknowledge Steven Boggs, William Cliett, Imicuk Loyuk, Mel Lucas, Anca Mirsu-Paun, Jennifer Woolard, Jennifer Luescher, and Ramona Chinn for their work on this project. Preliminary findings from the research were provided to the U.S. Department of Education, December 2003.

Declaration of Conflicting Interests - The authors declared no conflicts of interest with respect to the authorship and/or publication of this article.

Funding - The authors disclosed receipt of the following financial support for the research and/or authorship of this article: grant from the U.S. Department of Education: Fund for the Improvement of Education Program PR/Award Number R215U010016.

\section{References}

About Speak Up. (2006). Retrieved May 15, 2009, from www.paxusa.org/speakup/about.html

Anderson, C. S. (1982). The search for school climate: A review of the literature. Review of Educational Research, 52, 368-420.

Anderson, M., Kaufman, J., Simon, T. R., Barrios, L., Paulozzi, L., Ryan, G., \& Hammond, R., . . . School-Associated Violent Deaths Study Group. (2001). School-associated violent deaths in the United States, 1994-1999. Journal of the American Medical Association, 286, 2695-2702.

Astor, R. A., Benbenishty, R., Zeira, A., \& Vinokur, A. (2002). School climate, observed risky behaviors, and victimization as predictors of high school students' fear and judgments of school violence as a problem. Health Education and Behavior, 29, 716-736.

Bailey, S. L., Flewelling, R. L., \& Rosenbaum, D. P. (1997). Characteristics of students who bring weapons to school. Journal of Adolescent Health, 20, 261-270.

Beaver, K. M., Wright, J. P., \& Maume, M. O. (2008). The effect of school classroom characteristics on low self-control: A multilevel analysis. Journal of Criminal Justice, 36, 174-181.

Beger, R. R. (2003). The "worst of both worlds": School security and the disappearing fourth amendment rights of students. Criminal Justice Review, 28, 336-354.

Bellair, P. E., \& Roscignio, V. J. (2000). Local-labor market opportunity and adolescent delinquency. Social Forces, 78, 1509-1538.

Bellmore, A. D., Witkow, M. R., Graham, S., \& Juvonen, J. (2004). Beyond the individual: The impact of ethnic context and classroom behavioral norms on victims' adjustment. Developmental Psychology, 40, 1159-1172. 
Brank, E. M., Woolard, J. L., Brown, V. E., Fondacaro, M., Luescher, J. L., Chinn, R. G., \& Miller, S. A. (2007). Will they tell? Weapons reporting by middle-school youth. Youth Violence and Juvenile Justice, 5, 125-146.

Brinkley, C. J., \& Saarnio, D. A. (2006). Involving students in school violence prevention: Are they willing to help? Journal of School Violence, 5, 93-106.

Brookmeyer, K. A., Fanti, K. A., \& Henrich, C. C. (2006). Schools, parents, and youth violence: A multilevel, ecological analysis. Journal of Clinical Child and Adolescent Psychology, 35, 504-514.

Brown, B. (2004). Juveniles and weapons: Recent research, conceptual considerations, and programmatic interventions. Youth Violence and Juvenile Justice: An Interdisciplinary Journal, 2, 161-184.

Brown, B., \& Benedict, W. R. (2004). Bullets, blades, and being afraid in Hispanic high schools: An exploratory study of the presence of weapons and the fear of weapon-associated victimization among high school students in a border town. Crime and Delinquency, 50, 372-394.

Bryk, A. S., \& Raudenbush, S. W. (1992). Hierarchical linear models for social and behavioural research: Applications and data analysis methods. Newbury Park, CA: SAGE.

Burrow, J. D., \& Apel, R. (2008). Youth behavior, school structure, and student risk of victimization. Justice Quarterly, 25, 349-380.

Cao, L., Zhang, Y., \& He, N. (2008). Carrying weapons to school for protection: An analysis of the 2001 school crime supplement data. Journal of Criminal Justice, 36, 154-164.

Casella, R. (2003). Zero tolerance policy in schools: Rationale, consequences, and alternatives. Teachers College Record, 105, 872-892.

Catalano, R. F., Loeber, R., \& McKinney, K. C. (1999, October). School and community interventions to prevent serious and violent offending. Juvenile Justice Bulletin. NCJ 177624. Washington, DC: Office of Juvenile Justice and Delinquency Prevention.

Chen, G. (2008). Communities, students, schools and school crime. Urban Education, 43, 301-318.

Chen, G., \& Weikart, L. A. (2008). Student background, school climate, school disorder, and student achievement: An empirical study of New York City's middle schools. Journal of School Violence, 7, 3-20.

Clarke, R. V. (1997). Situational crime prevention: Successful case studies. New York, NY: Harrow \& Heston.

Cornish, D., \& Clarke, R. V. (1986). Introduction. In D. Cornish \& R. Clarke (Eds.), The reasoning criminal (pp. 1-16). New York, NY: Springer-Verlag.

De Vise, D. (2008, April 18). Suburban schools reject metal detectors. The Washington Post, A01.

Dinkes, R., Cataldi, E. F., \& Lin-Kelly, W. (2007). Indicators of school crime and safety: 2007 (NCES 2008021/NCJ 219553). Washington, DC: National Center for Education Statistics, Institute of Education Sciences, U.S. Department of Education, and Bureau of Justice Statistics, Office of Justice Programs, U.S. Department of Justice.

Elliott, D. S. (1983). National youth survey, Wave VI. Ann Arbor, MI: Inter-University Consortium for Political and Social Research.

Esposito, C. (1999). Learning in urban blight: School climate and its effect on the school performance of urban, minority, low-income children. School Psychology Review, 28, 365-377.

Estell, D. B., Farmer, T. W., Cairns, B. D., \& Clemmer, J. T. (2003). Self-report weapon possession in school and patterns of early adolescent adjustment in rural African American youth. Journal of Clinical Child and Adolescent Psychology, 32, 442-452.

Federal Gun Free School Act of 1994, 20 U.S.C. Chapter 20. 
Friman, P. C., Woods, D. W., Freeman, K. A., Gilman, R., Short, M., McGrath, A. M., \& Handwerk, M. L. (2004). Relationship between tattling, likeability, and social classification. Behavior Modification, 28, 331-348.

Garcia, C. A. (2004). School safety technology in America: Current use and perceived effectiveness. Criminal Justice Policy Review, 14, 30-54.

Gottfredson, G. D., Gottfredson, D. C., Payne, A. A., \& Gottfredson, N. C. (2005). School climate predictors of school disorder: Results from a national study of delinquency prevention in schools. Journal of Research in Crime and Delinquency, 42, 412-444.

Harcourt, B. (2000). After the "Social meaning turn": Implications for research design and methods of proof in contemporary criminal law policy analysis. Law and Society Review, 34, 179-211.

Kerbs, J. J., \& Jolley, J. M. (2007). The joy of violence: What about violence is fun in middle-school? American Journal of Criminal Justice, 32, 12-29.

Klepper, S., \& Nagin, D. (1989). The deterrent effect of perceived certainty and severity of punishment revisited. Criminology, 27, 721.

Koch, J. (2008, April 18). Tip line to promote gun-free schools. Chattanooga Times Free Press. Retrieved from http://www.timesfreepress.com/news/2008/apr/18/tip-line-promote-gun-free-school-zones/

Koth, C. W., Bradshaw, C. P., \& Leaf, P. J. (2008). A multilevel study of predictors of student perceptions of school climate: The effect of classroom-level factors. Journal of Educational Psychology, 100, 96-104.

Lleras, C. (2008). Hostile school climates: Explaining differential risk of student exposure to disruptive learning environments in high school. Journal of School Violence, 7, 105-135.

Loukas, A., \& Murphy, J. L. (2007). Middle school student perceptions of school climate: Examining protective functions on subsequent adjustment problems. Journal of School Psychology, 45, 293-309.

Malek, M. K., Chang, B.-H., \& Davis, T. C. (1998). Fighting and weapon-carrying among seventhgrade students in Massachusetts and Louisiana. Journal of Adolescent Health, 2, 94-102.

Mawson, A. B., Lapsley, P. M., Hoffman, A. M., \& Guignard, J. C. (2002). Preventing lethal violence in schools: The case for entry-based weapons screening. Journal of Health Politics, Policy $\mathcal{E}$ Law, 27, 243.

McNeely, C. A., Nonnemaker, J. M., \& Blum, R. W. (2002). Promoting school connectedness: Evidence from the national longitudinal study of adolescent health. Journal of School Health, 72, 138.

Murray, C., \& Murray, K. M. (2004). Child level correlations of teacher-students relationships: An examination of demographic orientation characteristics, academia orientations, and behavioral orientations. Psychology in the Schools, 41, 751-762.

Newman, R. S., Murray, B., \& Lussier, C. (2001). Confrontation with aggressive peers at school: Students' reluctance to seek help from the teacher. Journal of Educational Psychology, 93, 398-410.

Ochoa, G. M., Lopez, E. E., \& Elmer, N. P. (2007). Adjustment problems in the family and school contexts, attitude towards authority, and violent behavior at school in adolescence. Adolescence, 42, 779-794.

Orpinas, P., Murray, N., \& Kelder, S. (1999). Parental influences on students' aggressive behaviors and weapon carrying. Health Education \& Behavior, 26, 775-787.

Paternoster, R. (1989). Decisions to participate and desist from four types of common delinquency: Deterrence and the rational-choice perspective. Law and Society Review, 23, 7.

Payne, A. A. (2008). A multi-level analysis of the relationships among communal school organizations, students bonding, and delinquency. Journal of Research in Crime $\mathcal{E}$ Delinquency, 45, 429-455. 
Payne, A. A., Gottfredson, D. C., \& Gottfredson, G. D. (2003). Schools as communities: The relationships among communal school organization, student bonding, and school disorder. Criminology, 41, 749-777.

Pershing, J. (2003). To snitch or not to snitch? Applying the concept of neutralization techniques to the enforcement of occupational conduct. Sociological Perspectives, 46, 149-178.

Peterson, R. L., \& Skiba, R. (2001). Creating school climates that prevent school violence. The Social Studies, 92, 167.

Phillips, J., \& Springer, F. (1992). Extended National Youth Sports Program 1991-1992 evaluation highlights, part two: Individual Protective Factors Index and risk assessment study. In L. L. Dahlberg, S. B. Toal, \& C. B. Behrens (Eds.), Measuring violence-related attitudes, beliefs, and behaviors among youth: A compendium of assessment tools (1998). Atlanta, GA: Centers for Disease Control and Prevention.

Plucker, J. A. (1998). The relationship between school climate conditions and student aspirations. Journal of Educational Research, 91, 240-246.

Pratt, T. C. (2008). Rational choice theory, crime control policy, and criminological relevance. Criminology \& Public Policy, 7, 43-52.

Reinke, W. M., \& Herman, K. C. (2002). Creating school environments that deter antisocial behaviors in youth. Psychology in the Schools, 39, 549-560.

Reis, J., Trockel, M., \& Mulhall, P. (2007). Individual and school predictors of middle school aggression. Youth E Society, 38, 322-347.

Ruus, V., Veisson, M., Leino, M., Ots, L., Pallas, L., Sarv, E., \& Veisson, A. (2007). Students' wellbeing, coping, academic success, and school climate. Social Behavior and Personality, 35, 919-936.

Schleidlinger, S. (2003). The centrality of the peer group's role in two aspects of school violence revisited. International Journal of Group Psychotherapy, 53, 245-249.

Skiba, R., Reynolds, C. R., Graham, S., Sheras, P., Conoley, J. C., \& Garcia-Vasquez, E. (2006). Are zero tolerance policies effective in schools? An evidentiary review and recommendations. The American Psychologist, 63, 852-862.

Smith, S. W., Daunic, A. P., Miller, M. D., \& Robinson, T. R. (2002). Conflict resolution and peer mediation in middle schools: Extending the process and outcome knowledge base. Journal of Social Psychology, 142, 567-586.

Snell, C., Bailey, C., Carona, A., \& Mebane, D. (2002). School crime policy changes: The impact of recent highly publicized school crimes. American Journal of Criminal Justice, 26, 269-285.

Sprott, J. B. (2004). The development of early delinquency: Can classroom and school climates make a difference? Canadian Journal of Criminology and Criminal Justice, 46, 553-572.

Stewart, E. A. (2003). School social bonds, school climate, and school misbehavior: A multilevel analysis. Justice Quarterly, 20, 575-604.

Stewart, E. A., Schreck, C. J., \& Simons, R. J. (2006). “I ain't gonna let no one disrespect me”: Does the code of the street reduce or increase violent victimization among African American adolescents? Journal of Research in Crime and Delinquency, 43, 427-458.

Sullivan, J. (2002). School house hype: Two years later. Center on Juvenile and Criminal Justice Executive Summary. Retrieved October 7, 2004, from http://www.cjcj.org/pubs/schoolhouse/ shh2exec.html

Toby, J. (2002). Is a weapons-screening strategy for public schools good public policy? Journal of Health Politics, Policy E Law, 27, 261. 
Turner, M. G., Piquero, A. R., \& Pratt, T. C. (2005). The school context as a source of self-control. Journal of Criminal Justice, 33, 327-339.

U.S. Department of Education, U.S. Department of Justice Office of Justice Programs (2009). Indicators of School Crime and Safety: 2009 (NCES Publication No. 2010-012). Washington, DC: National Center for Educational Statistics. Retrieved from http://nces.ed.gov/pubs2010/2010012

Vossekuil, B., Fein, R. A., Reddy, M., Borum, R., \& Modzeleski, W. (2002). The final report and findings of the Safe School Initiative. Washington, DC: U.S. Secret Service and U.S. Department of Education.

Welsh, W. N. (2001). Effects of student and school factors on five measures of school disorder. Justice Quarterly, 18, 911.

Welsh, W. N. (2003). Individual and institutional predictors of school disorder. Youth Violence and Juvenile Justice, 1, 346-368.

Welsch, W. N., Greene, J. R., \& Jenkins, P. H. (1999). School disorder: The influence of individual, institutional, and community factors. Criminology, 37, 73-115.

Wilcox, P., \& Clayton, R. R. (2001). A multilevel analysis of school-based weapon possession. Justice Quarterly, 18, 509.

Wilcox Rountree, P. (2000). Weapons at school: Are the predictors generalizable across context? Sociological Spectrum, 20, 291-324.

\section{Author Bios}

Lindsey E. Wylie is both a graduate student and a law student in the Law and Psychology program at the University of Nebraska-Lincoln. She received her MA in forensic psychology from John Jay College of Criminal Justice. Her research focuses on legal issues affecting those across the lifespan, specifically elder caregiving, ageism, and juvenile justice.

Chris L. Gibson is an assistant professor in the Department of Sociology and Criminology \& Law at the University of Florida, a National Institute of Justice W. E. B. Du Bois Fellow, and a Jim Walter Partnership research affiliate at the University of South Florida. Using applied quantitative methods, his research focuses on neighborhood context and quality of life issues among children and adults, life-course criminology, and biosocial criminology.

Eve M. Brank is an assistant professor in the Department of Psychology, Law and Psychology and Social Psychology program at the University of Nebraska-Lincoln. Her research focuses primarily on legal and moral family obligations with juveniles or elders. This includes parental responsibility laws, general juvenile justice, school violence, caregiving of older adults, and ageist stereotypes.

Mark R. Fondacaro is a professor of psychology at John Jay College of Criminal Justice. He received his PhD in clinical psychology from Indiana University and his JD from Columbia University School of Law. His major research interests are ecological jurisprudence and the conceptualization and assessment of procedural justice in legal and extralegal contexts.

Stephen W. Smith is a professor in the Special Education Department at the University of Florida in Gainesville, Florida. He teaches courses in emotional and behavioral disorders and has conducted multiple federally funded investigations of effective behavior management techniques including the study of social conflict and the effects of school-wide peer mediation programs.

Veda E. Brown, a former assistant professor of psychology at Prairie View A\&M University in Texas, currently serves on the Violence Against Teachers K-12 Task Force of American Psychological Association: Center for Psychology in Schools and Education and consults with school districts on student safety. Her research areas include cognitive development in early childhood especially with reference to role of parents. She has also conducted extensive research to uncover factors associated 
Wylie et AL., Youth VIOLENCE AND JUVENILE JUSTICE 8 (2010)

with violent and/or aggressive behavior patterns in middle school students and the role of parents and hip-hop music in mediating such behaviors.

Scott A. Miller is a professor in the Department of Psychology at the University of Florida in Gainesville, Florida. His research areas include cognitive development in children and parents' beliefs about children. 